\title{
STRATEGI PENGELOLAAN STRES GURU WANITA BERSTATUS GURU TETAP YAYASAN SEKOLAH DASAR BERSISTEM FULL DAY SCHOOL
}

\author{
Dian Natalia Refti Farista \\ Universitas Negeri Malang, Jalan Semarang 5 Malang 65145 \\ E-mail: faristadian24@gmail.com
}

\begin{abstract}
This study aims to: (1) describe the source of stress; (2) the way the female teacher remains a foundation teacher (GTY) manages stress; and (3) the way schools manage the stress of female teachers of GTY status. Data collection is by interview, observation, and documentation and then check its validity using data credibility, member checking, and peer discussion; dependability; transferability; and data conformability. The results of this study were: (1) the source of stress of GTY female teachers in both research sites stemmed from three things: biological consisting of physical illness; psychological consisting of life demands at work or at home, conflict with others; and socio-cultural, namely the tasks that come together, both at home and at work; (2) stress management strategies undertaken by female teachers of GTY status include: determining priority scale; support from family and friends; out of routine; organize diet and exercise; increase the intensity of worship; and (3) stress management strategies for female teachers of GTY status conducted by schools that include: daily arranging daily work schedule, upholding team strength, daily dialogue, reading at least 1 juz, meeting needs based on pyramid Maslow; weekly ie outdoor learning, study of religion, giving motivation to employees; monthly salary on time; per semester ie working meeting in tourist place, giving working index; and annual recreation with teachers and students, giving awards in the coronation of outstanding teachers.
\end{abstract}

Keywords: stress management, female teacher, foundation teacher, full day school

\begin{abstract}
Abstrak: Penelitian ini bertujuan untuk: (1) mendeskripsikan sumber stres; (2) cara guru wanita berstatus guru tetap yayasan (GTY) mengelola stres; dan (3) cara sekolah mengelola stres guru wanita berstatus GTY. Pengumpulan data dilakukan dengan wawancara, observasi, dan dokumentasi kemudian dicek keabsahannya menggunakan kredibilitas data, pengecekan anggota, dan diskusi teman sejawat; dependabilitas; transferabilitas; dan konfirmabilitas data. Hasil penelitian ini adalah: (1) sumber stres guru wanita berstatus GTY di kedua situs penelitian bersumber dari tiga hal, yaitu: biologis yang terdiri dari sakit fisik; psikologis yang terdiri dari tuntutan hidup di tempat kerja maupun di rumah, konflik dengan orang lain; dan sosial budaya, yaitu tugas-tugas yang datangnya bersamaan, baik di rumah maupun di tempat kerja; (2) strategi pengelolaan stres yang dilakukan oleh guru wanita berstatus GTY meliputi: menentukan skala prioritas; dukungan dari keluarga dan teman; keluar dari rutinitas; mengatur pola makan dan olahraga; meningkatkan intensitas ibadah; dan (3) strategi pengelolaan stres guru wanita berstatus GTY yang dilakukan oleh sekolah yaitu meliputi: harian yakni mengatur jadwal kerja harian, menjunjung tinggi kekuatan tim, dialog harian, membaca Al Quran minimal 1 juz, pemenuhan kebutuhan berdasarkan piramida Maslow; mingguan yakni outdoor learning, kajian ilmu agama, pemberian motivasi pada karyawan; bulanan yakni pemberian gaji tepat waktu; per-semester yakni rapat kerja di tempat wisata, pemberian indeks kerja; dan tahunan yakni rekreasi bersama guru dan siswa, pemberian penghargaan berupa penobatan guru-guru berprestasi.
\end{abstract}

Kata kunci: pengelolaan stres, guru wanita, guru tetap yayasan, full day school

Guru merupakan salah satu dari daftar pekerjaan yang rentan stres. Secara biologis, wanita juga rentan stres. Apalagi secara sosial budaya, wanita dituntut untuk bisa melakukan berbagai tugas dalam satu waktu yang mana hal 31 
Pendidik harus memiliki kualifikasi akademik dan kompetensi sebagai agen pembelajaran (Gunawan, 2017; Hidayah, dkk., 2017); sehat jasmani dan rohani, serta memiliki kemampuan untuk mewujudkan tujuan pendidikan nasional. Pengejawantahan dari standar minimal tersebut menjadikan para pendidik sebagai garda terdepan pendidikan yang bersentuhan langsung dengan siswa wajib memiliki kestabilan emosi dan kesehatan ragawi yang mumpuni. Kompetensi guru sebagai agen pembelajaran pada jenjang pendidikan dasar dan menengah serta pendidikan anak usia dini meliputi: (1) kompetensi pedagogik; (2) kompetensi kepribadian; (3) kompetensi profesional; dan (4) kompetensi sosial.

Guru sebagai agen pembelajaran haruslah sehat jasmani dan rohani. Jika rohani atau psikis guru terganggu, maka salah satunya akibat stres, tentu akan berpengaruh pada pencapaian tujuan penyelenggaraan pendidikan dan mencederai peraturan serta tujuan pendidikan. Pada umumnya setiap pekerjaan selalu memiliki sumber stres yang potensial dan masing-masing jenis pekerjaan memiliki tingkat stressor yang bervariasi. Stres pada pekerja terjadi karena interaksi pekerja dengan pekerjaan atau lingkungan kerja yang ditandai dengan penolakan diri sehingga terjadi penyimpangan secara fungsional. Beberapa pekerjaan yang dianggap paling dapat membuat stres, yaitu: anggota militer, perawat, pelayan, guru (terutama dalam kota), penambang, pengatur lalu lintas udara, pemadam kebakaran, paramedis, pegawai pos, pialang saham, jurnalis, pilot pesawat, manajer tingkat menengah, sekretaris, polisi, petugas customer service.

Terdapat cukup bukti yang menunjukkan bahwa stres kerja berkaitan secara signifikan dengan keinginan guru meninggalkan profesi mengajar. Lebih dari itu, stres kerja berpengaruh pada peningkatan angka rata-rata ketidakhadiran guru setiap tahun dan peningkatan jumlah guru yang berhenti lebih dini (Gaziel, 1993; Kumintardjo dan Gunawan, 2017). Dalam sebagian besar kasus, perempuan menderita stres berlebih karena mereka melaksanakan peran ganda pada saat yang sama, seperti mengelola pekerjaan, keluarga, keuangan, dan lain-lain seperti disebutkan di atas. Mengidentifikasi penyebab dan gejala stres dapat membantu dalam mencari jalan keluar. Masalahmasalah yang berkaitan dengan kondisi berikut dapat menyebabkan stres pada wanita, yaitu masalah pekerjaan, masalah keuangan, masalah kesehatan, masalah dalam hubungan, kesendirian, kehamilan, kematian orang dekat, dan tekanan teman sebaya. Jika seorang guru wanita telah mengalami stres, maka agar dampak stres yang dialami tidak berlarut-larut diperlukan upaya pengendalian stres sejak dini atas kondisi tersebut. Pada dasarnya bahwa stres itu harus dikelola, diatur, dan dikendalikan dalam manajemen stres sehingga tidak menimbulkan penyimpangan psikologis.

\section{METODE}

Penelitian ini menggunakan pendekatan kualitatif karena menyangkut proses dan memerlukan pengamatan yang mendalam dalam situasi yang alami. Penelitian ini menggunakan rancangan studi multisitus karena melibatkan beberapa situs penelitian, yaitu SD IT Insan Permata dan SD Islam Assalam yang terletak di Kota Malang. Pemilihan dua situs tersebut didasarkan pada kesamaan karakteristik yang dimiliki oleh sekolah-sekolah tersebut.

Pengumpulan data dilakukan dengan teknik wawancara, observasi, dan dokumentasi yang dilakukan oleh peneliti dengan menghadiri situssitus penelitian secara terus-menerus. Kehadiran peneliti diketahui statusnya sebagai peneliti dan memiliki fungsi dalam menetapkan fokus penelitian, memilih situasi sosial dan informan sebagai sumber data, melakukan pengumpulan data, menilai kualitas data, menganalisis data, menafsirkan data, serta membuat kesimpulan dari hasil temuan di lapangan (Sugiyono, 2007; Gunawan, 2014).

Data dikumpulkan dari beberapa sumber data yang meliputi (1) informan yang sesuai kriteria peneliti, yaitu sudah menikah, memiliki anak, dan menjabat posisi tertentu di sekolah; (2) peristiwa atau aktivitas yang berkaitan dengan fokus penelitian; (3) Lokasi penelitian; (4) benda dan gambar yang berkaitan dengan fokus penelitian. Analisis data dilakukan melalui dua tekni yaitu analisis data dalam situs dan analisis data lintas situs. Analisis data dalam situs dilakukan melalui beberapa hal yaitu reduksi data, penyajian data, dan penarikan kesimpulan. Pengecekan keabsahan 
data merupakan bagian integral dari penelitian kualitatif. Pengecekan keabsahan data dilakukan dengan tiga cara menurut Guba dan Lincoln (1985) yang meliputi: (1) kredibilitas, (2) keteralihan, dan (3) dependabilitas.

\section{HASIL}

\section{Sumber Stres Guru Wanita Berstatus Guru Tetap Yayasan}

Sumber stres pada wanita yang bekerja menjadi guru berstatus GTY di sekolah bersistem full day school bisa berasal dari dirinya sendiri maupun dari luar dirinya. Stres yang berasal dari dalam diri bisa berasal dari gangguan biologis. Gangguan biologis yang dialami para guru wanita berstatus GTY ini bermacam-macam, ada yang disebabkan oleh alergi pada makanan tertentu, pengaruh cuaca, pengaruh aktivitas, dan lainlain. Selain karena pengaruh biologis, stres juga bisa timbul karena pengaruh sosial. Hubungan antara individu dengan individu lain, atau adanya tuntutan dalam hidup dan pekerjaan juga berakibat pada munculnya stres. Pada wanita yang bekerja sebagai guru GTY, stres karena pengaruh sosial itu bisa muncul ketika mereka sedang berinteraksi dengan para siswa, rekan, maupun keluarga.

Berdasarkan hal yang diungkapkan para guru wanita dalam penelitian ini, interaksi dengan siswa dapat menjadi hal yang mendatangkan stres serta menimbulkan dampak negatif maupun dampak positif. Ketika siswa merasa senang dan mudah diajak bekerja sama, guru menjadi lebih bersemangat mengajar yang merupakan dampak dari stres positif (eustress). Namun ketika siswa sedang tidak bisa diajak bekerja sama, dampak pada guru berupa stres negatif (distress) dalam bentuk marah atau jengkel. Dari kejadian di atas dapat disimpulkan bahwa interaksi dengan siswa dapat menjadi sumber stres bagi guru wanita berstatus GTY.

Di lingkungan rumah, para guru wanita SDIT Insan Permata dan SD Islam Assalam yang berstatus GTY mempunyai sumber stres yang rata-rata hampir dialami oleh semua wanita yang bekerja, yaitu mengatur pagi hari. Pagi hari adalah waktu yang sangat krusial bagi para perempuan yang bekerja karena waktunya sangat singkat dan yang dipersiapkan sangat banyak. Selain mempersiapkan untuk dirinya sendiri, para guru wanita berstatus GTY ini juga harus mempersiapkan anak-anaknya dan suaminya juga.

\section{Strategi Pengelolaan Stres oleh Guru Wanita Berstatus Guru Tetap Yayasan}

Cara pandang seseorang terhadap stres sangat menentukan cara seseorang tersebut dalam menangani stresnya. Cara pandang terhadap masalah menjadi hal yang sangat penting dalam pengelolaan stres karena berkaitan dengan reaksi atau respon para guru wanita berstatus GTY terhadap stres. Respon yang baik dan benar akan menstimulasi kreativitas dan mendorong kesuksesan. Respon buruk akan membuat mereka kehilangan keseimbangan dan mengakibatkan kinerja yang buruk pula. Sementara respon yang salah akan menyebabkan munculnya penyakit yang berakibat fatal. Hal ini terjadi karena cara pandang seseorang terhadap stres akan menentukan respon seseorang tersebut.

Untuk bisa mengelola stres, para guru wanita berstatus GTY harus mengenal gejala stresnya terlebih dahulu. Para guru wanita berstatus GTY di SDIT Insan Permata dan SD Islam Assalam mengungkapkan bahwa mereka sudah mengenal gejala stres mereka, baik stres positif maupun stres negatif. Cara pandang seseorang terhadap profesinya juga sangat memengaruhi tingkat stres serta pengelolaannya. Para informan penelitian di SDIT Insan Permata dan SD Islam Assalam mengaku menyukai pekerjaan mereka karena berbagai alasan, paling banyak adalah karena mereka memang menyukai pekerjaan mengajar. Ketika seseorang menyukai pekerjaannya maka mereka akan berusaha melakukan yang terbaik. Berbeda ketika seseorang kurang menyukai pekerjaannya maka yang akan terjadi adalah mudah bosan dan mudah stres. Peneriman terhadap pekerjaan juga memengaruhi kemampuan seseorang dalam mengelola stres.

Para guru wanita berstatus GTY yang bekerja di sekolah bersistem full day memiliki perbedaan dengan para guru wanita yang tidak berstatus GTY dan tidak bekerja di sekolah bersistem full day dalam hal hubungan dengan keluarganya. Dari segi waktu, para guru wanita berstatus GTY yang bekerja di sekolah bersistem full day memiliki waktu yang sangat singkat untuk bisa berkumpul 
dengan keluarga mereka. Pengaturan waktu untuk pekerjaan dan keluarga itu sangat penting agar keduanya bisa terpenuhi dengan baik sesuai porsinya. Para guru wanita berstatus GTY di SDIT Insan Permata dan SD Islam Assalam memiliki pengaturan waktu yang bervariasi untuk keluarga dan pekerjaan.

Masing-masing guru wanita berstatus GTY yang menjadi informan dalam penelitian ini memiliki solusi untuk mengatur waktu antara keluarga dan pekerjaan. Sebisa mungkin mereka mengagendakan waktu untuk berwisata bersama keluarga untuk menjaga rasa kebersamaan. Walaupun kegiatan di sekolah bersistem full day sangat padat, namun para guru wanita berstatus GTY ini mengatakan akan tetap bertahan di sekolah yang memulai aktivitasnya sejak jam 07.00 WIB dan berakhir pada jam 15.30 WIB ini. Ada banyak hal yang menyebabkan para guru wanita berstatus GTY ini bertahan di SDIT Insan Permata, diantaranya karena sudah merasa nyaman dengan suasana tempat mengajar, merasa nyaman dengan lingkungan sosial, dan mendapat dukungan penuh dari keluarga.

Dukungan dari keluarga dan lingkungan sosial juga sangat membantu seseorang dalam menjalani kehidupannya. Para guru wanita berstatus GTY ini mengatakan bahwa keluarga dan lingkungan sosial mereka sangat mendukung aktivitas mereka. Selain dukungan dari keluarga dan lingkungan sosial, para guru wanita berstatus GTY juga memiliki rasa spiritualitas yang tinggi, terutama di SD IT Insan Permata. Hal ini terbukti dengan adanya program membaca Al Quran sebanyak 1 juz setiap hari dan program refresh ruhiyah yang diadakan setiap pekan. Sedangkan di SD Islam Assalam, program spiritualitas untuk para guru hanya program refresh ruhiyah saja yang diadakan setiap pekan.

\section{Strategi Pengelolaan Stres Guru Wanita Berstatus Guru Tetap Yayasan oleh Sekolah}

SDIT Insan Permata sangat diperhatikan kesejahteraannya oleh kepala sekolah dan manajemen yayasan. Jenis perhatian yang diberikan berupa penggajian yang sesuai dengan jam kerja serta diberikan tepat waktu, pemberian penghargaan yang sepadan dengan usaha, pemberian tanggungjawab yang sesuai dengan kemampuan, pemberian beasiswa pada pegawai untuk bersekolah, dan kebebasan untuk mengusulkan program untuk kemajuan sekolah. Sumber Daya Manusia (SDM) dikelola dengan sangat baik sesuai dengan standar pengelolaan SDM yang dikeluarkan oleh yayasan, mulai dari perekrutan, penempatan, penggajian, dan pengembangan.

Semua tenaga pendidik dan tenaga kependidikan di SDIT Insan Permata mendapat beberapa tunjangan dan asuransi sebagai tambahan kesejahteraan, diantaranya asuransi kecelakaan dan tunjangan dana pensiun. Untuk guru yang sudah mengajar lebih dari 5 tahun mendapat tambahan asuransi pensiun. Dengan sistem humanis yang diterapkan oleh manajemen Insan Permata, Sri Susanti Tjahyadini yang menjabat sebagai bagian Manajemen Sumber Daya Manusia (manajemen SDM) mengklaim bahwa angka pegawai yang ikut CPNS sangat kecil. Hal yang menjadi dasar dalam pemberian tanggungjawab tambahan pada para guru wanita berstatus GTY ini antara lain mempertimbangkan kemampuan guru tersebut, melihat catatan-catatan kinerja para guru, dan mempertimbangkan masukan dari tim.

Ada cara lain yang juga digunakan oleh SDIT Insan Permata untuk menjaga para pegawai dari stres kerja, yaitu berupa dialog secara personal dengan para pegawai. Di tempat lain, dialog biasanya dilakukan ketika ada rapat, namun di SDIT Insan Permata dialog bisa dilakukan kapan saja tanpa harus menunggu rapat. Dengan strategi tersebut masalah bisa segera ditangani tanpa harus menunggu moment rapat. Menurut Sri Susanti Tjahyadini, teori segitiga kebutuhan yang dikemukakan oleh Maslow menjadi panduan bagi sekolah dalam menjaga guru dari stres. Teori kebutuhan yang dikemukakan oleh Maslow merupakan kunci bagi sekolah dalam pengelolaan sumber daya manusia. Oleh sebab itulah sekolah membebaskan para guru untuk berkreasi sebagai wujud dari pengaktualisasian dan penghargaan bagi para guru, selama kreasi mereka masih sejalan dengan visi dan misi sekolah.

Jenis perhatian yang diberikan di SD Islam Assalam berupa penggajian tepat waktu, pemberian tanggung jawab sesuai dengan kemampuan pegawai, serta memrogramkan rekreasi bersama. Strategi pengelolaan stres guru wanita berstatus GTY yang dilakukan oleh 
sekolah terbagi menjadi beberapa strategi. Strategi tersebut disusun berdasarkan waktu, yaitu harian, mingguan, bulanan, per-semester, dan tahunan. Strategi pengelolaan stres harian adalah strategi pengelolaan stres yang dilakukan setiap hari. Strategi pengelolaan stres harian dilakukan dengan mengatur jadwal kerja harian para guru. SD Islam Assalam adalah sekolah yang bersistem full day yang beroperasi dari jam 07.00 s.d. 15.30 WIB. Jadwal operasi tersebut berpengaruh pada jam mengajar guru yang mengajar hingga tiga kelas dalam sehari, oleh karena itu dibuatlah jadwal mengajar yang ramah guru. Jadwal mengajar yang ramah guru berupa pembuatan jadwal mengajar dengan memberikan jeda diantara jadwal yang ada.

Berikutnya adalah adanya dialog harian dengan Kepala Sekolah. Dialog harian di sini biasanya membicarakan tentang kendala-kendala yang dihadapi oleh para guru. Dengan metode dialog harian, para guru tidak harus menunggu rapat besar untuk mengeluhkan kendala-kendalanya. Hal ini menyebabkan cepatnya dilakukan perbaikan dan cepatnya ditemukan solusi dari kendala-kendala yang dialami guru. Strategi pengelolaan stres berikutnya adalah strategi pengelolaan stres yang dilakukan setiap minggu. Strategi pengelolaan stres mingguan yang pertama berupa student day. Student day merupakan proses belajar-mengajar yang dilakukan di luar sekolah atau kunjungan ke sumber belajar. Kegiatan ini merupakan kegiatan belajar yang dilakukan di dalam maupun luar sekolah namun sekaligus berfungsi sebagai sarana refreshing yang efektif bagi guru dan siswa. Kegiatan student day dilakukan secara berkala setiap hari Sabtu dengan melakukan kegiatankegiatan yang sifatnya mengasah kreatifitas siswa atau melakukan kunjungan ke suatu tempat yang sesuai dengan tema belajar siswa saat itu.

Strategi pengelolaan stres mingguan yang terakhir adalah pemberian motivasi pada karyawan. Pemberian motivasi diberikan pada saat rapat koordinasi yang dilakukan setiap hari Jumat. Pemberian motivasi ini berupa pemberian motivasi verbal yang dilakukan oleh Kepala Sekolah. Strategi pengelolaan stres berikutnya adalah strategi pengelolaan stres yang dilakukan setiap bulan sekali, berupa pemberian gaji tepat waktu. Selain gaji juga ada pemberian asuransi masa pensiun dan pemberian bonus yang berasal dari kehadiran dan kedisiplinan guru. Pemberian gaji tepat waktu ini adalah bentuk penghargaan pada segala hal yang telah dilakukan guru untuk sekolah. Strategi pengelolaan stres yang berikutnya adalah strategi pengelolaan stres yang dilakukan setiap semester berupa berwisata bersama. Wisata bersama ini dilakukan dua kali dalam satu semester dengan jadwal fleksibel, menyesuaikan dengan jadwal sekolah. Strategi pengelolaan stres yang terakhir adalah pengelolaan stres yang dilakukan dalam jangka waktu satu tahun. Kegiatan yang dilakukan adalah rekreasi bersama antara guru dan siswa kelas enam. Kegiatan ini bertujuan memberikan penyegaran pada guru dan siswa kelas enam setelah mengikuti ujian nasional.

\section{PEMBAHASAN}

Stres sesungguhnya telah ada sepanjang keberadaan manusia dan timbul sebagai hasil interaksi satu sama lain pada situasi yang sangat bervariasi. Istilah stres sendiri berasal dari istilah Latin yaitu dari kata stringere yang mempunyai arti ketegangan dan tekanan. Stres merupakan hal yang melekat pada kehidupan. Siapa dan di mana saja, dalam kadar berat ringan yang berbeda dan dalam jangka waktu yang tidak sama, pernah atau akan mengalaminya. Bayi bisa terkena stres, balita bisa terkena stres, kaum remaja pun tak luput dari stres. Orang dewasa akan mengalami stres, demikian pula dengan kelompok lansia, laki-laki dan perempuan. Salim dan Salim (2002) menjelaskan stres memiliki dua pengertian, yaitu: (1) gangguan atau kekacauan mental dan emosional; dan (2) tekanan. Secara teknis psikologik, stres didefinisikan sebagai suatu respon penyesuaian seseorang terhadap situasi yang dipersepsinya menantang atau mengancam kesejahteraan orang bersangkutan (Hawari, 2001).

Selye (1985) mengemukakan bahwa stres adalah respons umum tubuh terhadap suatu tuntutan. Definisi itu didasarkan pada indikator obyektif seperti perubahan jasmani dan kimiawi dalam tubuh sesudah adanya tuntutan atau tekanan dari lingkungan. Ivancevich (2006) mengemukakan yang dimaksud dengan stres adalah suatu respon adaptif, dimoderasi oleh perbedaan individu yang rnerupakan konsekuensi dari setiap tindakan, situasi, atau peristiwa, yang memberikan tuntutan khusus terhadap seseorang. Stres atau tekanan adalah terminologi umum untuk menunjukkan 
adanya perasaan tertekan pada kehidupan pekerja. Selain itu stres juga dapat diartikan sebagai apa saja yang menstimulasi dan rneningkatkan tingkat kewaspadaan. Hidup tanpa stimulus akan sangat membosankan. Hidup dengan terlalu banyak stimulus menjadi tidak menyenangkan dan melelahkan, dan dapat merusak kesehatan.

Hasil penelitian menyebutkan bahwa terlalu banyak stres dapat sangat memengaruhi kinerja. Hawari (2001) menyatakan manajemen atau penatalaksanaan stres, cemas, dan depresi pada tahap pencegahan dan terapi memerlukan suatu metode pendekatan yang bersifat holistik, yaitu mencakup fisik (somatik), psikologik/ psikiatrik, psikososial, dan psikoreligius. Di bidang pencegahan agar seseorang tidak jatuh dalam keadaan stres, cemas, dan/atau depresi maka sebaiknya kekebalan yang bersangkutan perlu ditingkatkan agar mampu menanggulangi stresor psikososial yang muncul dengan cara hidup yang teratur, serasi, selaras, dan seimbang antara dirinya dengan Tuhan (vertikal), sedangkan secara horizontal antara dirinya dengan sesama orang lain dan lingkungan alam sekitarnya.

Freeman dan Freeman (2013) menyatakan bahwa kaum wanita berisiko $40 \%$ lebih besar untuk mengalami gangguan psikologi (stres) dibanding kaum pria. Wanita cenderung menjadi lebih lelah ketika mereka menghadapi situasi stres. Dalam sebagian besar kasus, perempuan menderita stres berlebih karena mereka melaksanakan peran ganda pada saat yang sama, seperti mengelola pekerjaan, keluarga, dan keuangan. Wanita rentan mengalami depresi, gangguan panik, fobia, insomnia, gangguan stres pascatrauma, serta gangguan pola makan (Freeman dan Freeman, 2013; Hidayah, dkk, 2017). Mengidentifikasi penyebab dan gejala stres dapat membantu dalam mencari jalan keluar. Gejala fisiologis yang dialami seseorang yang sedang stres ditandai dengan kelelahan kronis, tekanan darah tinggi, penyakit pencernaan, dan penyakit jantung, denyut jantung yang tinggi dan tangan berkeringat, sakit kepala, sesak napas, konstipasi (sembelit), sakit punggung atau pundak, gangguan tidur, gangguan menstruasi, dan perubahan berat badan yang drastis (Steers, 1984). Kepala sekolah memiliki tanggung jawab untuk mengelola stres pada guru agar dapat meningkatkan kinerja (Gunawan, 2015).
Secara aspek kognitif atau pikiran, stres ditandai dengan lupa akansesuatu, sulit konsentrasi, cemas mengenai suatu hal, sulit memproses informasi, dan mengemukakan pernyataanpernyataan negatif terhadap diri sendiri. Gangguan psikologis muncul dalam bentuk ketidakstabilan emosi, ketegangan emosional, kegelisahan, kecemasan, mudah panik, sikap mudah marah, sering menangis, mengalami peningkatan konflik interpersonal, dan frustasi (Steers, 1984). Sedangkan gangguan perilaku meliputi kehilangan nafsu makan atau terlalu banyak makan, kesulitan tidur, menjadi perokok, peminum alkohol, atau menyalahgunakan obat-obatan (Atkinson, dkk., 1991; Kusmintardjo dan Gunawan, 2017). Looker dan Gregson (2004) juga menggolongkan stres menjadi dua golongan. Penggolongan ini didasarkan atas persepsi individu terhadap stres yang dialaminya, yaitu: (1) distress, merupakan stres yang merusak atau tidak menyenangkan. Stres dirasakan sebagai suatu keadaan di mana individu merasa cemas, ketakutan, khawatir atau gelisah, sehingga individu mengalami keadaan psikologis negatif, menyakitkan, dan timbul keinginan untuk menghindarinya; dan (2) eustress, merupakan stres yang bersifat menyenangkan dan merupakan pengalaman yang memuaskan.

Rice (1992) menyebutkan sebagai frase joy of stress untuk mengungkapkan hai-hal yang bersifat positif yang timbul dari adanya stres. Eustress juga dapat meningkatkan motivasi individu untuk menciptakan sesuatu. Misalnya meningkatkan karya seni. Hardjana (1994) menyatakan sumber-sumber stres dibagi menjadi dua, yaitu: internal dan eskternal. Internal, stres dapat bersumber dari penyakit (illness) dan pertentangan (conflict) dalam diri. Menderita penyakit membawa tuntutan psikis dan psikologis pada orang yang menderitanya. Konflik terjadi di mana seseorang tidak dapat memilih salah satu atau lebih macam kebutuhan dan tujuan. Terdapat empat jenis konflik, yaitu: (1) konflik pendekatan ganda (approach-approach conflict), konflik ini rnelibatkan dua alternatif yang sama-sama rnenyenangkan atau positif; tetapi tidak rnungkin rnencapai keduanya sekaligus dalam waktu yang sama; (2) konflik penolakan ganda (avoidanceavoidance approach), kebalikan dari konflik pendekatan ganda, konflik ini melibatkan dua 
alternatif yang sama-sama tidak menyenangkan; (3) konflik penolakan-pendekatan (avoidanceapproach conflict), konflik yang memiliki tujuan rnenyenangkan namun di lain pihak tidak menyenangkan, konflik ini rnerupakan konflik yang paling sulit diselesaikan dan menimbulkan kebingungan bagi mereka yang menghadapinya karena di lain pihak mereka menginginkan tujuan yang menyenangkan sedangkan di sisi lain mereka mendapatkan konsekuensi yang tidak menyenangkan; dan (4) konflik penolakanpendekatan ganda (multiple approach avoidance conflict), konflik yang banyak terjadi, di mana kita harus membuat keputusan dari kedua altematif yang keduanya sama-sama memiliki konsekuensi yang positif danjuga yang negatif.

Ekstemal, termasuk di dalamnya adalah tekanan-tekanan lingkungan yang bersifat eksternal, baik lingkungan kerja, lingkungan keluarga, maupun lingkungan masyarakat. Selye (1985) mengemukakan bahwa stressor kerja ada empat macam: (1) extra organizational stressors, yang terdiri dari perubahan sosial/teknologi, keluarga, relokasi, keadaan ekonomi dan keuangan, ras dan kelas, dan keadaan komunitas/timpat tinggal; (2) organizational stressors, yang terdiri dari kebijakan organisasi, struktur organisasi, keadaan fisik dalam organisasi, dan proses yang terjadi dalam organisasi; (3) group stressors, yang terdiri dari kurangnya kebersamaan dalam grup, kurangnya dukungan sosial, serta adanya konflik intraindividu, interpersonal, dan intergroup; dan (4) individual stressors, yang terdiri dari terjadinya konflik dan ketidakjelasan peran, serta disposisi individu seperti pola kepribadian tipe a, kontrol personal, learned helplessness, self-efficacy, dan daya tahan psikologis.

$$
\text { Looker dan Gregson (2004) }
$$

mengemukakan beberapa penyebab wanita lebih rentan mengalami stres daripada pria, yaitu: biologis, psikologis, dan sosial budaya. Faktor biologis, susunan genetika antara pria dan wanita sangat berbeda. Wanita memiliki susunan genetika yang cenderung mudah terserang stres. Hal ini berkaitan dengan pengaruh perubahan hormonal yang terjadi di dalam tubuh wanita. Tubuh wanita cenderung mudah terpengaruh perubahan hormonal dibanding tubuh pria. Faktor psikologis, sebagian besar wanita adalah tipe pemikir keras. Wanita cenderung memikirkan suatu hal dengan sangat mendalam. Padahal terlalu banyak berpikir, meskipun hal itu bertujuan positif untuk menanggulangi suatu masalah, menyebabkan wanita rentan terserang stres. Faktor sosial budaya, wanita adalah makhluk yang multitasker. Seorang wanita harus mampu menangani banyak hal dalam waktu bersamaan, seperti mengerjakan tugas kantor, mengurus rumah, mengurus suami, dan mengurus anak. Hal ini menjadi pemicu stres yang kuat pada wanita. Ketika wanita menyadari adanya gejala stres dalam dirinya, mereka dapat menemukan cara untuk mengatasinya. Teknik self-help terbukti efektif dapat membantu dalam mengurangi kadar stres.

Beberapa teknik yang efektif untuk manajemen stres bagi para wanita: (1) dukungan, dukungan dari keluarga dan teman-teman dapat membantu wanita dalam manajemen stress secara signifikan. Hal ini menyebabkan kemungkinan menderita gejala stres menjadi lebih rendah; (2) bersikap positif, wanita harus ingat bahwa stres tidak hanya menimpa dirinya saja. Situasi stres muncul dalam kehidupan semua orang sehingga dibutuhkan sikap positif untuk menghadapi stresnya. Dalam sebagian besar kasus, ketika dalam situasi stres, wanita cenderung melebihlebihkan hal yang sebenarnya sederhana saja; (3) mengatur pola makan dan olahraga, pola makan dan olahraga memainkan peran penting dalam pengelolaan stres. Meditasi dan yoga juga populer untuk manajemen stres, khususnya latihan pernapasan, sangat efektif dan dapat dilakukan di rumah, di mobil atau bahkan di tempat kerja; (4) perempuan harus mengambil istirahat dari rutinitas Menyalurkan hobi secara teratur juga bagus untuk mengurangi stres besar. Kegiatan sederhana seperti menghabiskan waktu dengan keluarga, jalan bersama teman-teman atau pijat relaksasi dapat membantu dalam mengurangi stres dan ketegangan; (5) mengikuti metode sederhana seperti diet seimbang, tidur malam yang baik, menghindari penundaan kerja, 
mengelola dan memanfaatkan waktu dengan baik, mendelegasikan pekerjaan, memiliki komunikasi yang mudah dengan anggota keluarga, dll dalam jangka panjang dapat membantu untuk mengurangi stres; dan (6) jika mengalami stres di luar kendali dan tidak dapat menyingkirkan efeknya, lebih baik segera meminta bantuan profesional. Dengan cara ini gangguan kesehatan yang disebabkan stres bisa dicegah.

\section{KESIMPULAN DAN SARAN}

\section{Kesimpulan}

Bertolak dari temuan penelitian dan pembahasan, hasil penelitian dapat disimpulkan sebagai berikut. Stres guru wanita berstatus GTY di kedua situs penelitian bersumber dari tiga hal, yaitu: (1) biologis, yang terdiri dari sakit fisik; (2) psikologis, yang terjadi sebagai imbas dari interaksi sosial di tempat kerja maupun di rumah. Dalam berinteraksi dengan siswa kadangkala guru wanita berstatus GTY merasa stres ketika siswa susah diajak bekerja sama atau ketika nilai siswa berada di bawah KKM. Dalam berinteraksi dengan teman sejawat kadangkala juga menjadi sumber stres psikologis bagi para guru wanita karena terjadi konflik di antara mereka dengan teman sejawatnya. Dalam berinteraksi dengan keluarga, kadangkala juga timbul konflik yang menyebabkan guru wanita berstatus GTY merasa stres; dan (3) sosial budaya.yaitu adanya budaya bahwa wanita harus mampu menyelesaikan beberapa macam tugas dalam waktu yang bersamaan sebagai akibat dari adanya peran ganda.

Strategi pengelolaan stres meliputi: (1) menentukan skala prioritas; (2) dukungan dari keluarga dan teman; (3) keluar dari rutinitas; (4) mengatur pola makan dan olahraga; dan (5) meningkatkan intensitas ibadah. Strategi pengelolaan stres guru wanita berstatus GTY oleh sekolah meliputi: (1) strategi pengelolaan stres harian: mengatur jadwal kerja harian, dialog harian, membaca Al Quran minimal 1 juz, pemenuhan kebutuhan berdasarkan piramida Maslow; (2) strategi pengelolaan stres mingguan: outdoor learning, kajian ilmu agama, pemberian motivasi pada karyawan; (3) strategi pengelolaan stres bulanan: pemberian gaji; (4) strategi pengelolaan stres per-semester: rapat kerja di tempat wisata, pemberian indeks kerja; dan (5) tahunan: rekreasi bersama guru dan siswa, pemberian penghargaan berupa penobatan guru-guru berprestasi.

\section{Saran}

Berdasarkan simpulan di atas, maka saran/ rekomendasi yang diajukan bagi Dinas Pendidikan disarankan untuk lebih memerhatikan kesehatan psikologis para guru agar guru dapat bekerja dengan maksimal dengan cara mengadakan koordinasi dengan para kepala sekolah untuk mengembangkan program pengelolaan stres seperti yang dilakukan di SDIT Insan Permata dan SD Islam Assalam. Bagi guru wanita berstatus GTY di kedua sekolah disarankan untuk mengenal lebih dalam lagi tentang hal-hal yang dapat menyebabkan diri mereka merasakan stres negatif dan gejala-gejalanya, sehingga penanganan stres dapat segera dilakukan sesuai dengan gejala yang dirasakan dan kerugian akibat stres dapat dihindari.

Bagi Kepala SD Islam Assalam dan Yayasan Assalam disarankan untuk mengadakan: (1) strategi pengelolaan stres harian bagi para pegawai berupa: (1) mengorganisasi pembacaan Al Quran di sekolah dengan membentuk grup membaca $\mathrm{Al}$ Quran khusus guru dengan tujuan meningkatkan sisi spiritualitas dan semakin mendekatkan hubungan antar-guru; (2) membangun kekuatan tim melalui pendelegasian sehingga tugas-tugas yang berpotensi menimbulkan stres pada guru dapat diminimalisasi; (2) strategi pengelolaan stres persemester bagi pegawai berupa penyelenggaraan moment khusus untuk pemantapan visi misi sekolah pada para guru dengan tujuan meningkatkan motivasi para guru, khususnya guru wanita berstatus GTY; dan (3) strategi pengelolaan stres tahunan bagi pegawai berupa penghargaan dengan mengadakan penobatan guru-guru berprestasi untuk meningkatkan motivasi para guru wanita berstatus GTY pada khususnya dan seluruh guru pada umumnya.

Bagi Kepala SD IT Insan Permata dan Manajemen LPIT adalah strategi pengelolaan stres tahunan disarankan untuk mempertahankan dan meningkatkan program strategi pengelolaan stres dengan variasi lain yang disesuaikan dengan guru wanita, misalnya pemberian tiket wisata untuk guru wanita beserta keluarganya, mengingat sebagian 
besar waktu mereka sudah dihabiskan di sekolah. Bagi peneliti selanjutnya, disarankan untuk menindaklanjuti hasil penelitian ini dan mengkaji lebih mendalam tentang strategi pengelolaan stres pada tenaga pendidik agar dunia pendidikan makin berkembang.

\section{DAFTAR RUJUKAN}

Atkinson, R. L, Atkinson, R. C., dan Hilgard, E. R. 1991. Penghantar Psikologi. Jakarta: Erlangga.

Freeman, J., dan Freeman, D. 2013. The Stressed Sex: Uncovering the Truth About Men, Women, and Mental Health. Oxford: Oxford University Press.

Gaziel, H. H. 1993. Coping With Occupational Stress Among Teachers: A Cross-Cultural Study. Journal of Comparative Education, 29(11), 67-79.

Guba, E. G., dan Lincoln, Y. S. 1985. Effective Evaluation: Improving the Usefulness of Evaluation Results Through Responsive and Naturalistic Approaches. San Francisco: Jossey-Bass Publishers.

Gunawan, I. 2014. Metode Penelitian Kualitatif: Teori dan Praktik. Jakarta: PT Bumi Aksara.

Gunawan, I. 2015. Pengaruh Kepemimpinan Transformasional dan Kepuasan Kerja terhadap Perilaku Kewargaan Organisasi Guru Sekolah Dasar Negeri Kecamatan Kras Kabupaten Kediri. Premiere Educandum, 5(1), 59-81.

Gunawan, I. 2017. The Application of Instructional Management Based Lesson Study and its Impact with Student Learning Achievement. Proceeding 2nd International Conference on Educational Management and Administration (CoEMA), Theme: The Challenges of Educational Management and Administration in Global and Local Era, Jurusan Administrasi Pendidikan Fakultas Ilmu Pendidikan Universitas Negeri Malang, Malang, Published by Atlantis Press, hlm. 4-12.
Hardjana, A. 1994. Stres tanpa Distres: Seni Mengolah Stres. Yogyakarta: Kanisius.

Hawari, D. 2001. Manajemen Stres, Cemas, dan Depresi. Jakarta: FK UI.

Hidayah, N., Hardika, Hotifah, Y., Susilawati, S. Y., dan Gunawan. Psikologi Pendidikan. Malang: Universitas Negeri Malang, UM Press.

Ivancevich, J. M. 2006. Perilaku dan Manajemen Organisasi. Terjemahan oleh Gina Gania. Jakarta: Erlangga.

Kumintardjo, dan Gunawan, I. 2017. Manajemen Layanan Khusus. Malang: Universitas Negeri Malang, Penerbit UM Press.

Looker, T., dan Gregson, O. 2004. Managing Stress. Terjemahan oleh Haris Setiawati. Yogyakarta: Buku Baik.

Rice, P. L. 1992. Stress dan Health. California: Brooks/Cole Publishing Company.

Salim, P., dan Salim, Y. 2002. Kamus Bahasa Indonesia Kontemporer. Jakarta: Modern English Press.

Selye, H. 1985. History and Present Status of the Stress Concepts. Dalam Monat, A., dan Lazarus, R. S., (Eds.), Stress and Coping: An Anthology. New York: Columbia University Press.

Steers, R. M. 1984. Efektivitas Organisasi. Terjemahan oleh Magdalena Jamin. Jakarta: Erlangga.

Sugiyono. 2007. Metode Penelitian Kuantitatif, Kualitatif, dan R dan D. Bandung: Alfabeta. 